\title{
Determinants of scientific output: an in-depth view of the productivity of tropical botanist and conservationist, Luis Diego Gómez Pignataro
}

\author{
Julián Monge-Nájera ${ }^{1,2}$, Vanessa Nielsen-Muñoz ${ }^{2}$ \& Ana Beatriz Azofeifa ${ }^{3}$ \\ 1. Laboratorio de Ecología Urbana, Universidad Estatal a Distancia, San José, Costa Rica; julianmonge@gmail.com \\ 2. Revista de Biología Tropical, Universidad de Costa Rica; vnielsen.rbt@gmail.com \\ 3. Escuela de Bibliotecología y Ciencias de la Información, Universidad de Costa Rica; abazofeifa@gmail.com
}

Received 26-V-2010. Corrected 01-VII-2010. Accepted 06-VIII-2010.

\begin{abstract}
Bibliometric studies have found that male researchers have their greatest productivity around the age of 40 , that female researchers produce less than their male colleagues, that incentives for collaboration are slow to affect productivity and that, just like humans, research institutes become larger, less productive, more expensive to maintain and less able to raise money as they grow old. Almost invariably, these conclusions come from statistical studies of large numbers of European and American scientists, and there are practically no studies about tropical researchers. We present an in-depth analysis of the productivity of an internationally recognized tropical botanist and conservationist, Luis Diego Gómez Pignataro, based on the totality of his published work and on our own knowledge, as co-workers and friends, of the life frame in which that scientific output was produced. His life output departs from the expected pattern in that he had the highest productivity before reaching the expected peak productivity age, and that when he reached it his productivity fell and never recovered. Furthermore, marriage did not produce the expected fall in productivity. A close analysis of his life indicates that in the middle of his career he switched to intense teaching and conservation activities, and this better explains why his output of scientific research articles was low afterwards. This switch may occur in other tropical scientists. Rev. Biol. Trop. 58 (4): 1093-1114. Epub 2010 December 01.
\end{abstract}

Key words: bibliometry, productivity, differences among tropical and temperate scientists, science in "developing countries", conservation and science.

Scientific productivity generally follows a known curve along the life of researchers. There are famous exceptions such as the French entomologist Jean Henri Fabre, who made most of is vast contribution after the age of 50 , but basically, output increases to reach a peak around the time when the researchers are 40 years old and declines with old age, usually after the $60^{\text {th }}$ birthday (Kyvik 1990). Not only productivity, but also the "quality label" that society gives to productivity, is higher for the first years of productivity. This applies to all fields, including music, literature, cinematography, mathematics and biology. For example, Paul McCartney, J.D. Salinger, Orson Welles, John von Neumann and James D. Watson did not make any significant contributions after their young years (Kanazawa 2003). In the words of Albert Einstein (cited by Brodetsky 1942, p. 699): “A person who has not made his great contribution to science before the age of thirty will never do so".

The patterns for productivity vary to some extent among scientific fields. In the social sciences, for example, the output remains approximately the same in all age groups, while authors in the humanities tend to have a final peak after the age of 60 years (Kyvik 1990).

More recent studies have asked new questions, such as: Is the pattern the same for women and men?, what is the effect of collaboration on 
productivity? Or, do institutions show the same "life pattern" as people?

Female researchers produce less than their male colleagues (Kelchtermans \& Veugelers 2008) and follow throughout life a flattened version of the male productivity curve; the same is true for female musicians and fiction writers (Kanazawa 2003). The reasons for the lower productivity of women have traditionally been explained as the result of social limitations, but a biological cause must also be considered (Kanazawa 2003).

How incentives for collaboration affect productivity has been studied in research networks funded by the European Union. During the period of funding, collaboration does not produce an increase in productivity. But productivity after the funding period increases (Defazio et al. 2009).

A study of the Italian National Research Council data found that, just like humans, research institutes become larger, less productive, more expensive to maintain and less able to raise money as they grow old (Bonaccorsi \& Daraio 2003).

To come to such conclusions, the great majority of studies have done correlation analyses on samples of hundreds of researchers (Kanazawa 2003, Defazio et al. 2009), but few have done in-depth observations on individual lives. Besides, almost the totality of studies deal with European or American scientists (Kyvik 1990, Defazio et al. 2009) ignoring the rest of the world's scientific community. In these times of danger for the tropical ecosystems where the majority of biodiversity is found, it is particularly shocking that no such studies exist for tropical researchers.

Our contribution in this article is that we present an in-depth analysis of the productivity of an internationally recognized tropical botanist and conservationist, Luis Diego Gómez Pignataro, based on the totality of his published work and on our own knowledge, as co-workers and friends, of the life frame in which that scientific output was produced.

\section{MATERIALS AND METHODS}

The scientific output was obtained from various sources: "Luis Diego Gómez: Personal Bibliography" Organization for Tropical Studies (www.ots.ac.cr), the online-catalogues (OPAC) of Universidad de Costa Rica and Universidad Nacional (www.ucr.ac.cr and www. una.ac.cr), the ISI Web of Science and Google Academic, as well as interviews and other information supplied by close associates and relatives familiar with his work. His book reviews, published for years in the Revista de Biología Tropical (www.biologiatropical. ac.cr) were not included. The information was processed with the bibliographies manager ProCite.

The Collaboration Index (CI) was calculated with the formula: $\mathrm{CI}=$ number of authors per publication/number of publications.

\section{RESULTS}

Luis Diego was one of the most outstanding Latin American botanists of the $20^{\text {th }}$ century (Bohlen 1993) and his mini-autobiography is now available (Bohlen 1993). His productive career covered 39 years (1968-2009), in which he produced 181 articles that were published in a total of 37 journals. The overall mean was 4.6 articles per year but in 1982 he published 15 articles (mostly of the Plantae Mesoamericanae Novae series) and 23 articles and other works were published in 1983, many as chapters in Costa Rican Natural History (Janzen 1983).

He also published 41 other works that included books, book chapters, meeting presentations, booklets and maps, and he edited several books by other authors (Table 1).

Half of his articles appeared in international journals published in Costa Rica, one third in the USA and the rest in European, Latin American and Asian journals published in a total of 10 countries (Table 1).

His favorite journals to publish were Brenesia, Biología Tropical, American Fern Journal and Phytologia (Appendix 1). 
TABLE 1

Country of publication for journals and other printed out put

$\begin{array}{lccc}\text { Country } & \text { Number of articles } & \text { Number of journals } & \text { Other publications* } \\ \text { Costa Rica } & 95 & 7 & 25 \\ \text { USA } & 56 & 13 & 14 \\ \text { Germany } & 10 & 5 & 1 \\ \text { Great Britain } & 7 & 5 & \\ \text { Argentina } & 3 & 1 & \\ \text { Japan } & 3 & 1 & \\ \text { Canada } & 1 & 1 & \\ \text { France } & 1 & 1 & \\ \text { Italy } & 1 & 1 & \\ \text { Honduras } & 1 & 1 & \\ \text { No data } & 3 & 1 & \\ \text { Total } & 181 & 37 & \\ \text { *Books, maps, among others; see main text. } & & \end{array}$

Nearly $60 \%$ of his articles were in English, the rest were mostly in Spanish but he also wrote two in German and one in Italian.

$\mathrm{He}$ was the single author in $63 \%$ of his articles, with a collaboration index of 1.79 . His most frequent co-authors were Jorge GómezLaurito, Liuba Kisimova-Horovitz, Rolf Singer and Eckhard Wollenweber. He also published 44 articles with one coauthor, 22 with two, five with three, five with four and five articles with more than four coauthors (Appendix 2).

The productivity curve has many peaks but for articles his greatest output was during the first 20 years of his career. For other publications such as books and maps, he peaked 15 and again 25 years after the beginning. There are three basic time trends in productivity: his output on fungi remained fairly constant throughout his life; the output on ferns had three large peaks in the first 20 years and the output on angiosperms was zero in the first 10 years, it peaked and was kept low afterwards (Fig. 1).

The greatest output was on ferns, fungi and angiosperms (Fig. 2). The complete list of publications appears in Appendix 3.

\section{DISCUSSION}

Early life: In the decade of 1990 , scientists started to publish internationally at the age of 35, but when Luis Diego Gómez Pignataro began his career in 1968, he was within the standard documented for that period by Bonaccorsi \& Daraio (2003), which was around 25 years.

His interest in tropical nature was born in an era in which Costa Rica was experiencing a population boom and the agro-export model was the country's accepted "path to development". The tropical forest was seen as a frontier to conquer, as described by the Costa Rican novelist Fabian Doubles in El sitio de las abras (Dobles 1950), a novel that describes the place and time in which Luis Diego grew up. He started publishing the results of his scientific research in the late 1960s but years before, when he was a child growing up amid the dense Caribbean rainforest, he had already begun studying the family garden, reading natural history books and creating his own plant classification system based on morphological 

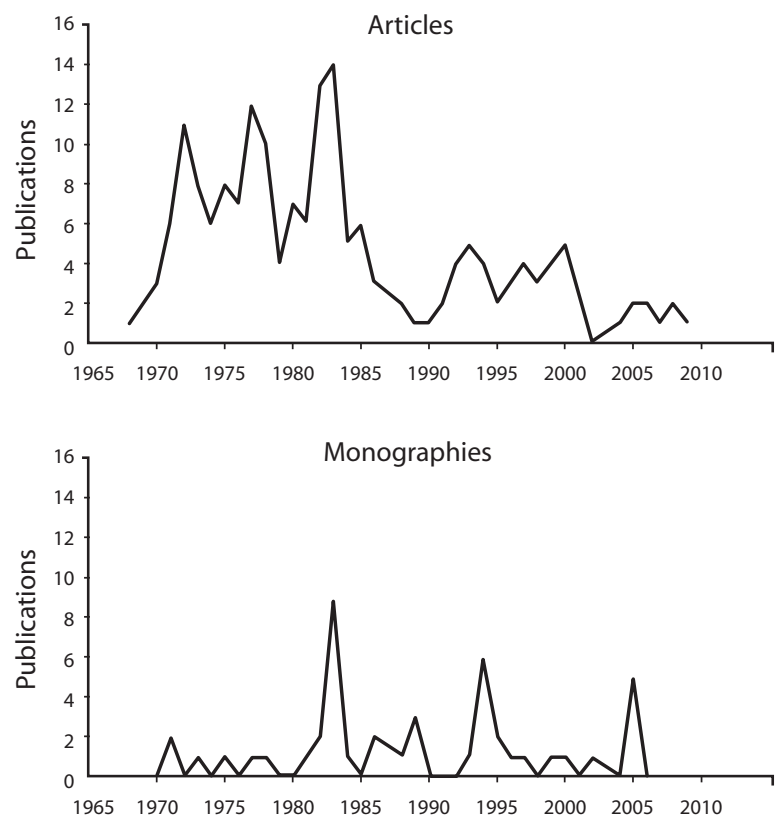

Fig. 1. Luis Diego Gómez Pignataro: total production by year and type of publication, 1968-2010.

characteristics (Bohlen 1993). Thus started a productive career that lasted the typical spam of around 40 years (Kyvik 1990).

Productivity: In the USA, a study based on 443 academic scientists found that productivity is related to being male, tenured, married and non-native, and that chemists have the highest per capita productivity while scientists in computer science have the lowest (Bozeman \& Lee 2003). The number of articles per author increased along the $20^{\text {th }}$ century. In the 1930s, scientists peaked at three articles per year, while that working in the 1960's averaged four articles per year (Hall et al. 2003). More recently, the number of yearly international publications per researcher varies from none to 20 but three is typical for Europe (Bonaccorsi \& Daraio 2003). The productivity of Luis Diego (4.6 articles per year) can be considered average for good international researchers. Considering that he almost never asked for research funds, his output is extraordinary and shows a known but seldom mentioned finding: that the most outstanding researchers often get far less financing than their mediocre colleagues (Bonaccorsi \& Daraio 2003, Kelchtermans \& Veugelers 2008).

The unusually high productivities of 1982 and 1983 probably reflect the fact that the Plantae Mesoamericanae Novae series was a field that he knew well and that the chapters in Costa Rican Natural History were short: we believe that both required less time than more complex scientific papers and thus his output was higher in these years.

Young researchers tend to produce work of higher quality (Kelchtermans \& Veugelers 2008) but we did not study if this applies to the work by Luis Diego.

The 1980s was a period of great transformation in Luis Diego's life. After achieving in 1986 what has been called the National Museum's Second Golden Age, he left to pursue another major rescue project, one that appeared to be a lost cause: what is now the Wilson Botanical Garden. 

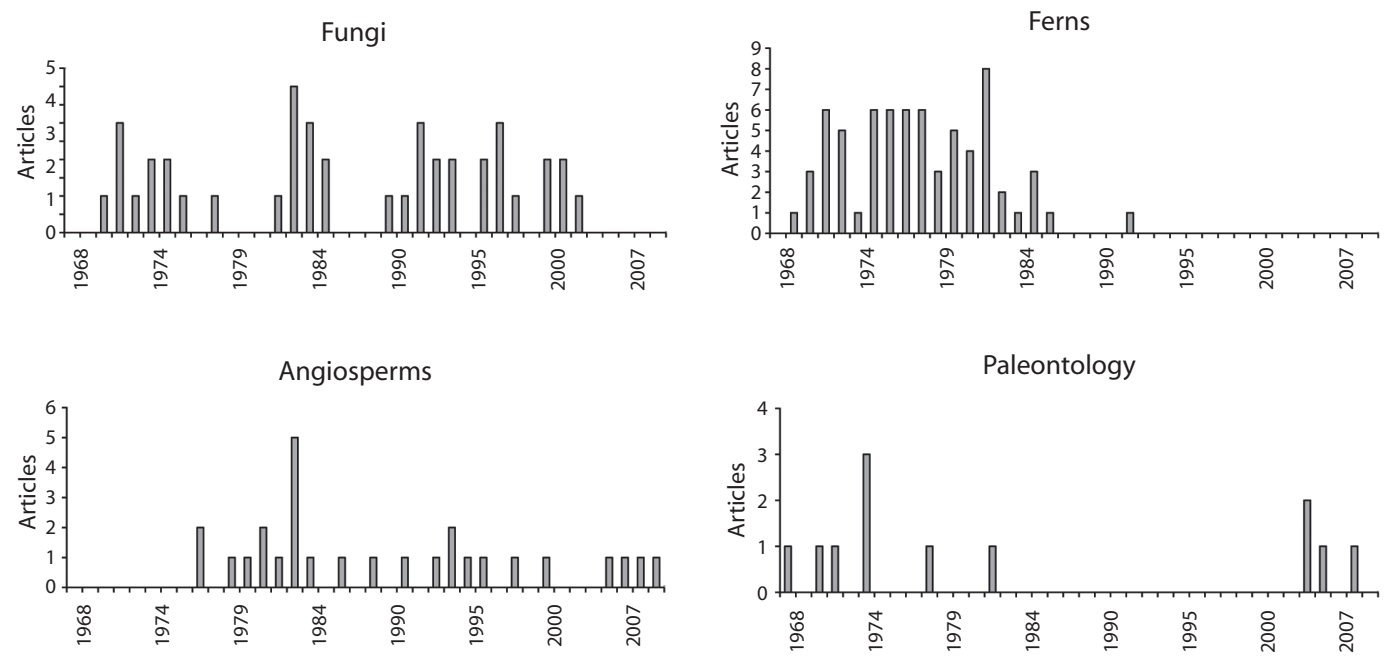

Interactions

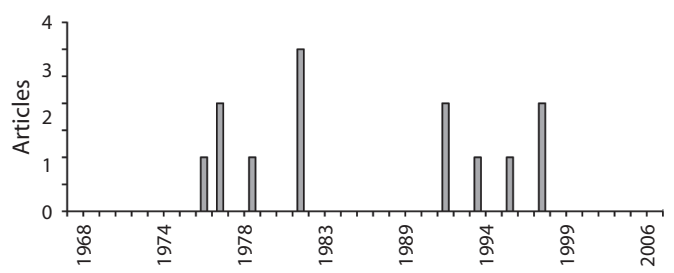

Fig. 2. Luis Diego Gómez Pignataro: total production by subject, 1968-2010.

As a result of his effort and ability to motivate those around him, from construction workers to scientists and donors, the garden became an international research center and scored the highest rating as a destination for ecotourism. The garden is also an internationally recognized documentation and conservation center, an achievement seen by the local community as their own actions thanks to outreach efforts and environmental education. It is visited annually by biology students from the U.S., Europe and several other regions, and Luis Diego played several simultaneous roles in keeping the garden as a leader in the region.

All this administrative effort did not prevent him from publishing. He designed a fern key that is essential to any current Central American fern ecology and conservation research. He also studied the extraordinary resistance of ferns to herbivore attack and their biogeographic origin, a subject that he continued to work on until it was extended to all Costa Rica paleo-biogeography. Perhaps his most striking description was his paper on the first American fern preserved in amber, which he called Grammitis succinea (Gómez 1982). He found time to continue the series on fungi taxonomy that he had begun in the previous decade and to describe the gastronomic preferences of a squirrel when offered fungi, in the most classic style of natural history.

In the field of history and drawing from his Latin knowledge, he wrote an article on the Roman naturalist Pliny the Elder and how his view influenced the attitude of Spaniards and Latin Americans towards fungi (Gómez 1983). 
Supporting talented young people may be the best investment in science (Wallner et al. 2003) and Luis Diego was well known for practicing this idea. Gail Hewson, his second wife tells us about his time as head of the Costa Rica National Museum Natural History Department between 1970 and 1985:

"Luis Diego's botany and taxonomy contribution impress beyond words. He had a formidable career within Costa Rica's National Museum. It is almost impossible to browse a guide to identification of any Costa Rican flora and fauna group without finding recognition to Luis Diego, for his time, energy and collaboration".

\section{Rafael Ángel Chacón adds:}

"In 1972, when I was only 16 years old, I started to work at the National Museum of Costa Rica. There I met Mr. Luis Diego Gómez. At that time he was the General Director, Natural History Section Chair and the National Herbarium Director. Don Luis, as he was known, called me to be part of the National Herbarium staff, which by that time had 45000 specimens mounted and cataloged, with much material stored in cardboard boxes. He taught me my first steps in the natural sciences. Under his management, the Natural History Section changed its name to Natural History Department. As the collections were scattered throughout various parts of the museum, with hard work and dedication he built the Natural History Building.

As a person and leader he was outstanding. We shared many things, both personal and workrelated. In March 1984, I had the wonderful experience of walking for 22 days by his side, climbing Fabrega Peak in Panama. On the third day we wanted to come back due to the weather. In the tent everything was completely wet and he said "Look, if tomorrow we wake-up with more rain, we'll turn around and go back". Fortunately, the next morning the sun shined. The following days, the cold pierced my bones but Luis Diego, always looking ahead, told us: "We will make it!". To talk about Luis Diego there is only one word in the dictionary: naturalist; he was a true one, an expert on our natural history like there are very few".

Journals where he published: Like other scientists, he tried to spread his articles among a variety of journals in the hope of reaching a wider audience but concentrated on a few. Brenesia was the natural history journal that he had founded in the Museum. To our knowledge, he was not criticized for publishing in his own journal, perhaps this was not an issue because the quality of his work was so widely recognized. He sent many manuscripts to Biología Tropical and a possible reason was that the Revista is one of the leading journals in tropical research and it has its offices in Costa Rica. The American Fern Journal and Phytologia were also good options for him because they are specialized in his field of work.

Perhaps his most seminal contribution in the editorial field was the creation of the journal Brenesia, which honors Costa Rica's first graduate biologist, botanist Alberto Brenes. Brenesia quickly became a major scientific journal, with authors of great prestige, thanks to his skillful editorship. Brenesia's foundation was within a broader renewal context, because Luis Diego was Director of Costa Rica National Museum Department of Natural History between 1970 and 1985, bringing the museum not only out of the decline it had suffered after World War II but achieving in that time the recognition of an active international center for botanical and entomological research.

Language: English dominates the scientific productivity of the world (Monge-Nájera \& Nielsen 2005). In the case of Luis Diego, his command of the English language was impressive, so is not surprising that he wrote nearly $60 \%$ of his articles in the language of science but the fact that he also wrote almost $40 \%$ in Spanish is harder to explain. Maybe he wanted to make those articles more accessible to technicians and students. Perhaps he published in German and Italian just "for fun" (Italian was the language of his mother). He also had 
knowledge of Aramaic, Latin and Russian. Ana Victoria Lizano says:

"His relationship with Dr. Rafael Lucas Rodriguez was very close. Among their common passion was the love for Latin who he also shared with Jorge Gómez Laurito. It seems that exchanging letters and messages in Latin was among their hobbies".

Collaboration: In recent decades, collaboration leading to coauthorship has been the norm: the mean number of collaborators for one year's research work is nearly 14 , of which $41 \%$ are graduate students and $27 \%$ are women (Bozeman \& Lee 2003). Researchers spend $84 \%$ of their time working in collaboration and researchers with more collaborators publish more articles (Bozeman \& Lee 2003). Collaborative projects are often done to capitalize on funding opportunities but in the long run they tend to increase researcher productivity (Defazio et al. 2009). By modern standards, Luis Diego was a lonely author with only $37 \%$ of his articles done in collaboration, possibly because others found it hard to follow his rhythm of work. Even so, he published repeatedly with several colleagues, particularly Jorge Gómez-Laurito, who was both cousin and a tropical botanist; Liuba Kisimova-Horovitz, a German mycologist who visited Costa Rica several times (they shared their love for long walks in the forest); Rolf Singer, the famous German botanist, had been his mentor in earlier years and Eckhard Wollenweber, a leading German researcher in natural products (Luis Diego was always interested in the uses of tropical plants and published a Botany of the Central Market column in the Wilson Garden's Amigos Newsletter).

Fields of work: Brilliant researchers tend to work in many fields, in contrast with the rest of their colleagues; classical examples of the first group include Leonardo da Vinci and Benjamin Franklin. Even though the greatest output from Luis Diego came in the areas of ferns, fungi and angiosperms, his published work covered many other areas and besides excelling in botany and natural history he was also a gifted illustrator and a pianist. Ana Victoria Lizano says:

"Since the times of high school, Luis Diego was a passionate music lover. He played the violin and the piano very well and I think that even gave some public concerts".

During the 1970s he defined what would be his major working areas. He described palms, bromeliads, algae, fossil figs and horsetail plants, updating the approach by reconstructing not only the organism but also the environmental conditions in which it lived. This was a model for later research on Costa Rica's paleoclimate and paleo-ecosystems. He started the series Flora Costaricensis, which has continued to appear for more than three decades in the prestigious Fieldiana: Botany. He also described new fungi and fern species in various journals, always with excellent illustrations from his own hand.

$\mathrm{He}$ rescued Costa Rican lichens from oblivion with his research on basidiolichens, which years later would help make possible a dozen other studies from different authors on lichens as bioindicators of air pollution in Costa Rican cities. He published papers on the taxonomy and geographical distribution of fungi and ferns, from places as diverse as Central America, Easter Island and the Venezuelan Guyana. It was also during this period that Luis Diego began publishing about one of his favorite places, Cocos Island, where he studied subjects ranging from plants to flies that were associated with crabs.

He also made some incursions into ecology when he worked with ants associated with Polypodium plants (Gómez 1973) and with Trigona bees that collect plant gums (Ramírez \& Gómez 1978).

He also pioneered historical analyses of Costa Rican science, with biographies of the Swiss botanist Hermann Crist, who described many Central American ferns (Gómez 1977) and the deeply human story of Swiss botanist 
Charles Wercklé, who sadly ended his days as an alcoholic in $19^{\text {th }}$ Century Costa Rica (Gómez 1978).

Giving recognition to Costa Rican biologist Clodomiro Picado Twight, who published the first large ecological study of bromeliad ecology in the early $20^{\text {th }}$ Century, Luis Diego published The Biology of Bromeliads, which was to be the first issue of a new serial publication called Historia Natural de Costa Rica, which he was unable to continue.

He annoyed some by dedicating his book Costa Rican Vegetation "to the bureaucrats, without whose help I would have done more and better" and made some deep comments on the role of egos in Costa Rica science, for example commenting that the Costa Rican National Academy of Science was useless and included some people who should not be there while excluding some who should be in (Gómez 1994). Fortunately for him, apparently few -if any- ever read that book.

Effect of marriage on productivity: The higher productivity that characterizes earlier life in fields as varied as art, science and crime, may be a manifestation of young men's competitive desire to gain access to women's reproductive resources (Kanazawa 2003). The idea of a biological origin, explained because higher productivity would have increased male reproductive success in the ancestral environment, is supported by another interesting observation: marriage has a strong "desistance effect" on the productivity of male scientists and artists: men's evolved psychological mechanism to be highly competitive in early adulthood seems to "turn off" when they get married, have children and experiment a reduced level of testosterone (Kanazawa 2003).

Luis Diego married in 1970 (Bohlen 1993) and had a son, yet his productivity did not decrease (the marriage, however, lasted only 6 years). One change in his life that should have reduced his productivity was the administrative burden that he had as director of the Natural History Department (National Museum) from 1970 through 1985. Yet this reduction did not occur. Besides the articles, he published 41 other works that included whole books, book chapters, meeting presentations, booklets and maps. In the decade of 1980, he made assessments for the National Park Service, which were handed over to the authorities to improve their administrative work. He also published specialized articles on tropical ferns, conservation of natural ecosystems and botanical gardens and about horticulture in Costa Rica.

In 1989 he married for the second time, but again there was no immediate change in his productivity. During this period, he published several studies on the phytochemistry of Neotropical plants and made three major contributions in book form. On one hand, he played a central role as co-author and sponsor of the essays in Costa Rican Natural History, published in English by the University of Chicago and in Spanish by University of Costa Rica.

In this regard, Gail Hewson, states:

\begin{abstract}
"Probably his most accessible and widely read work is the first chapter in Costa Rican Natural History, entitled "Searchers on That Rich Coast: Costa Rican Field Biology, 1400-1980" (written with Jay Savage). His other contributions to this collection include "Marsh Fern", "Tree Ferns", "Parasitic Plants" and "Ferns" (with Warren H. Wagner). Certainly this fascinating and information rich book tops the list of "Required Readings" for students and travelers even though it was first published more than 20 years ago!".
\end{abstract}

On the other hand, he was the author of Costa Rica's Aquatic and Amphibious Plants (Gómez 1984) and the principal author of Costa Rica's Flora and Climate (Herrera \& Gómez 1993) both published by the Universidad Estatal a Distancia de Costa Rica. His work on aquatic plants would become a key reference for the study and conservation of wetlands in Costa Rica, and Costa Rica's Flora and Climate still is the principal compendium on the country's climate, plant ecology and paleoecosystems.

Possible effect of garden's work on productivity: The marked reduction in his 
personal productivity came when he left the National Museum and started work in the Wilson Botanical Garden. The scientific productivity of the Museum also fell noticeably after he left, not only in quantity but also in quality (and has not recovered to this date). In fact, Luis Diego's output was lower after he started working intensively in conservation and in saving the botanical garden. Gail Hewson remembers this period:

\begin{abstract}
"The garden's recovery after the terrible fire of 1994 was the work of many committed individuals and foundations, but none worked harder than Luis to ensure it. The Amigos Newsletter went from being a simple letter to OTS friends and staff members, to a very popular quarterly newsletter for visitors, who sought to keep their memories of the garden alive through the colorful, humorous and enlightening prose that characterized Luis. Who can forget his column Botany in the Central Market and his reflections on everything from tropical medicine, nature's color, the protocol to transform a meadow in a forest or the wisdom of the local shamans. $\mathrm{He}$ had the wonderful gift of being able to awake interest and even occasional controversy among scientists and laypersons alike".
\end{abstract}

He also found time to work, with much clearer way, in conservation, combining his duties in the botanical garden with publications on Costa Rica's tropical biodiversity, paramo's ecology and conservation and Costa Rica's southern region common trees and birds names. Simultaneously, he became active in the scientific articles publication on fungi systematic, plant physiology and phytochemistry.

During the third decade, even though his output was lower, he made occasional forays into other fields, such as participating in the redescription of the snake Bothrops supraciliaris (Solórzano et al. 1998) and understanding the bird's role in dispersal of the primitive plant Zamia's (Gómez 1993), a species particularly striking because it survived the CretaceousTertiary extinction (65.5 million years ago) with few changes.
After 2000 he continued his work on the Flora Costaricensis, published more on fungal taxonomy and showed that he was still interest in biogeography with the publication of the important Central America's Ecosystems Map (Vreugdenhil et al. 2002).

The great fire and its effect on his motivation: Shortly after the fire in the garden, he told one of us (JMN): "My collection of San Vito insects burned during the fire. The next day, a nice beetle landed so close that I captured it with my hand. I told myself 'this is the beginning of my new collection', but then I thought of all that I had lost and let it fly away". Then he showed stacks of manuscripts he kept in a drawer and added: "I have all these, but I will never publish them. I no longer feel like it, I think it will make no difference if I publish them or not". This could explain the fall in his productivity, but it does not: the dramatic reduction in productivity had begun years before, just after he left the Museum. What did he lose when he left, that affected his output so much?

Two hypotheses are that he was too busy teaching and that he no longer felt a need to contribute articles to Brenesia.

Luis Diego was a passionate man and this included his teaching activities. He personally participated in the graduate and undergraduate courses taught at the Wilson Botanical Gardens, lecturing and acting as a guide in field trips. Unofficial data in the OTS files indicate that from 1986 to 2008 there were 177 graduate courses with 3566 students. Additionally there were 56 undergraduate courses. Luis Diego was program coordinator in six of the eight Ethnobiology courses taught in Costa Rica, attended by a total of 103 students, participated in similar courses in Peru and even got scholarhips for some Peruvian students to travel to Costa Rica (Guiselle Castro, OTS, pers. com.). He also spent time hosting many visiting scientists and student group, so it is easy to see that he did not have much free time to write and we accept this hypothesis as a good candidate to explain the reduction in his productivity. 
The "Journal Hypothesis": Future researchers may test the other hypothesis: that during the museum years he felt the need to write for Brenesia because the journal did not receive enough manuscripts and that he published far less after he left the journal because he no longer felt responsible for filling it up.

Conclusion: The 222 publications that Luis Diego Gómez Pignataro contributed to world science are an extraordinary output for a lifetime but he might have produced even more if he had stayed in an European or American research center, with access to far superior resources. Nevertheless, like so many other scientists (as found by Bonaccorsi \& Daraio 2003), he chose to stay in his native land, to the great benefit of Latin American biology.

\section{ACKNOWLEDGMENTS}

From the University of Costa Rica we thank Jorge Gómez Laurito for information and advice, and from the OTS we thank Guiselle Castro for data and Mariana Mora for the interviews reproduced here (our translation).

\section{RESUMEN}

Los estudios bibliométricos han encontrado que los investigadores de sexo masculino tienen su mayor productividad aproximadamente a los 40 años; que las investigadoras producen menos que sus colegas masculinos, que los incentivos para la colaboración tardan en aumentar la productividad y que, al igual que los seres humanos, los institutos de investigación se hacen más grandes, menos productivos, más costosos y menos capaces de recaudar dinero a medida que envejecen. Casi siempre, estas conclusiones provienen de estudios de un gran número de científicos europeos y estadounidenses, y prácticamente no hay estudios sobre los investigadores tropicales. Aquí presentamos un análisis detallado de la productividad de un botánico y conservacionista tropical reconocido internacionalmente, Luis Diego Gómez Pignataro, basado en la totalidad de su obra publicada y en nuestro propio conocimiento de su vida como compañeros de trabajo y amigos. $\mathrm{Su}$ vida se aparta del patrón esperado en que tuvo su mayor productividad en los primeros 20 años de carrera y produjo comparativamente poco en los siguientes 20 años. Además, el matrimonio no produjo el descenso esperado en su productividad. Justo a la mitad de su carrera se dedicó intensamente a actividades de enseñanza y conservación, lo que explica esa baja en su producción. Este patrón podría darse en otros científicos tropicales.

Palabras clave: bibliometría, productividad, diferencias entre científicos tropicales y de zonas templadas, ciencia en "países en desarrollo", conservación y ciencia.

\section{REFERENCES}

Bohlen, J.T. 1993. For the wild places: profiles in conservation. Island, Washington, D.C.

Bonaccorsi A. \& C. Daraio. 2003. Age effects in scientific productivity. Scientometrics 58: 49-90

Bozeman, B. \& S. Lee. 2003. The Impact of Research Collaboration on Scientific Productivity. Annual Meeting of the American Association for the Advancement of Science. February. Denver, Colorado, USA.

Brodetsky, S. 1942. Newton: Scientist and man. Nature 150: 698-699.

Defazio D., A. Lockett \& M. Wright. 2009. Funding incentives, collaborative dynamics and scientific productivity: Evidence from the EU framework program. Res. Policy 38: 293-305.

Dobles, F. 1950. El sitio de las abras. Editorial Costa Rica, San José, Costa Rica.

Gómez, L.D. 1973. Ants and Polypodium polypodioides. Amer. Fern J. 63: 166.

Gómez, L.D. 1977. Contribuciones a la pteridología costarricense. XI. Hermann Crist, su vida, obra e influencia en la botánica nacional. Brenesia 12/13: 25-79.

Gómez, L.D. 1978. Contribuciones a la pteridología costarricense XII. Carlos Wercklé. Brenesia 14/15: 361 93.

Gómez, L.D. 1982. Grammitis succinea, the first new world fern found in Amber. Am. Fern J. 72: 49-52.

Gómez, L.D. 1983. De Fungi: una selección de Plinio el Viejo. Brenesia 21: 437-47

Gómez, L.D. 1993. Birds as short-range seed dispersers of Zamia fairchildiana in SW Costa Rica. Rev. Biol. Trop. 41: 905-906.

Gómez, L.D. 1994. Las ciencias naturales, p. 173-182. In O. Morales (ed.). Ideario Nacional de la Ciencia y la Tecnología : Hacia el nuevo milenio. Ministerio de Ciencia y Tecnología. San José, Costa Rica. 
Gómez, L.D.1984. Las plantas acuáticas y anfibias de Costa Rica y Centroamérica I. Liliopsida. EUNED, San José, Costa Rica.

Bohlen, J.T. 1993. Luis Diego Gómez: behind the scenes botanist, p. 118-146. In For the wild places: profile in conservation, Island, Washington, D.C., USA.

Herrera, W. \& L.D. Gómez. 1993. Mapa de unidades bióticas de Costa Rica San José: (Escala 1:685 000). INCAFO, Madrid, España.

Janzen, D.H. (ed.). 1983. Costa Rican Natural History, University of Chicago, Chicago, Illinois, USA.

Kanazawa, S. 2003. Why productivity fades with age: The crime-genius connection. J. Res. Personality 37: 257-272.

Kelchtermans, S. \& R. Veugelers. 2008. The great divide in scientific productivity: Why the average scientist does not exist. Department of Managerial Economics, Katholieke Universiteit, Leuve, Belgium.
Kyvik, S. 1990. Age and scientific productivity. Differences between fields of learning. Higher Educ. 19: 37-55.

Hall, B.H., J. Mairesse \& L. Turner. 2003. Identifying Age, Cohort and Period Effects in Scientific Research Productivity: Discussion and Illustration Using Simulated and Actual Data on French Physicists. SPRU Conference in Memory of Keith Pavitt, 13-15 November, University of Sussex, Sussex, England.

Wallner, B., M. Fieder \& K. Iber. 2003. Age profile, personnel costs and scientific productivity at the University of Vienna. Scientometrics 58: 143-153.

Ramírez B.W. \& L.D. Gómez. 1978. Production of nectar and gums by flowers of Monstera deliciosa (Araceae) and of some species of Clusia (Guttiferae) collected by New World Trigona bees. Brenesia 14/15: 407-412.

Vreugdenhil, D., J. Meerman, A. Meyrat, L.D. Gómez \& D.J. Graham. 2002. Map of the Ecosystems of Central America: Final Report. World Bank, Washington, D.C., USA

\section{APPENDIX 1}

Titles of periodicals and publishers by country

\begin{tabular}{|c|c|c|c|}
\hline Titles of periodicals & $\begin{array}{l}\text { No. of } \\
\text { manuscripts }\end{array}$ & Country & Publishing house \\
\hline Brenesia & 51 & Costa Rica & $\begin{array}{l}\text { Museo Nacional de Costa Rica. } \\
\text { Departamento de Historia Natural }\end{array}$ \\
\hline Revista de Biología Tropical & 34 & Costa Rica & Universidad de Costa Rica \\
\hline Lankesteriana & 4 & Costa Rica & $\begin{array}{l}\text { Universidad de Costa Rica. } \\
\text { Jardín Botánico Lankester }\end{array}$ \\
\hline Revista Geológica de América Central. & 3 & Costa Rica & $\begin{array}{l}\text { Universidad de Costa Rica. } \\
\text { Escuela Centroamericana de Geología }\end{array}$ \\
\hline Biocenosis & 1 & Costa Rica & $\begin{array}{l}\text { Universidad Estatal a Distancia. } \\
\text { Centro de Educación Ambiental. }\end{array}$ \\
\hline $\begin{array}{l}\text { Historia Natural de Costa Rica. Biología } \\
\text { de las Bromeliáceas }\end{array}$ & 1 & Costa Rica & $\begin{array}{l}\text { Museo Nacional de Costa Rica. } \\
\text { Departamento de Historia Natural }\end{array}$ \\
\hline O’Bios & 1 & Costa Rica & $\begin{array}{l}\text { Universidad de Costa Rica. } \\
\text { Boletín de la Escuela de Biología }\end{array}$ \\
\hline American Fern Journal & 20 & USA & The American Fern Society \\
\hline
\end{tabular}


APPENDIX 1 (Continued)

Titles of periodicals and publishers by country

\begin{tabular}{|c|c|c|c|}
\hline Titles of periodicals & $\begin{array}{l}\text { No. of } \\
\text { manuscripts }\end{array}$ & Country & Publishing house \\
\hline Phytologia & 13 & USA & Texensis Publishing \\
\hline Fieldiana. Botany & 5 & USA & Chicago Natural History Museum \\
\hline American Journal of Botany & 3 & USA & Botanical Society of America \\
\hline Annals of the Missouri Botanical Garden & 3 & USA & Missouri Botanical Garden \\
\hline Biotropica & 2 & USA & $\begin{array}{l}\text { Association of Tropical Biology } \\
\text { and Conservation }\end{array}$ \\
\hline Bulletin of the Torrey Botanical Club & 2 & USA & Torrey Botanical Society \\
\hline Journal of the Lepidopterists' Society & 2 & USA & The Lepidopterists' Society \\
\hline Mycotaxon & 2 & USA & Mycotaxon \\
\hline BioScience & 1 & USA & American Institute of Biological Sciences \\
\hline Botanical Gardens Newsletter & 1 & USA & $\begin{array}{l}\text { University of California Botanical Garden, } \\
\text { Berkeley }\end{array}$ \\
\hline Heliconia Society International Bulletin & 1 & USA & Heliconia Society International \\
\hline The Coleopterists Bulletin & 1 & USA & The Coleopterists Society \\
\hline Nova Hedwigia & 3 & Germany & $\begin{array}{l}\text { Schweizerbart and Borntraeger } \\
\text { Science Publishers }\end{array}$ \\
\hline $\begin{array}{l}\text { Zeitschrift für Naturforschung. Section C, } \\
\text { Biosciences }\end{array}$ & 3 & Germany & Verlag \\
\hline Biochemical Systematics and Ecology & 2 & Germany & Elsevier \\
\hline Beiträge zur Biologie der Pflanzen & 1 & Germany & Duncker \& Humblot \\
\hline $\begin{array}{l}\text { Veröffentlichungen aus dem Übersee- } \\
\text { Museum Bremen }\end{array}$ & 1 & Germany & Museum Bremen \\
\hline Fern Gazette & 2 & England & British Pteridological Society \\
\hline $\begin{array}{l}\text { Proceedings of the Royal Society of } \\
\text { Edinburgh }\end{array}$ & 2 & Great Britain & The Royal Society of Edinburgh. \\
\hline $\begin{array}{l}\text { Studies on Neotropical Fauna and } \\
\text { Environment }\end{array}$ & 1 & Great Britain & Taylor \& Francis \\
\hline The Mycologist & 1 & Great Britain & The British Mycological Society \\
\hline $\begin{array}{l}\text { Transactions of the British Mycological } \\
\text { Society }\end{array}$ & 1 & Great Britain & The British Mycological Society \\
\hline Chemical \& Pharmaceutical Bulletin & 3 & Japan & Pharmaceutical Society of Japan, \\
\hline Darwiniana & 3 & Argentina & Instituto de Botánica "Darwinion"- \\
\hline Canadian Journal of Botany & 1 & Canada & National Research Council \\
\hline $\begin{array}{l}\text { Atti dell'Istituto Botanico e Laboratorio } \\
\text { Crittogamico dell'Universitá di Pavia. } \\
\text { Serie } 6\end{array}$ & 1 & Italy & $\begin{array}{l}\text { Istituto Botanico e del Laboratorio } \\
\text { Crittogamico dell'Universita di Pavia. }\end{array}$ \\
\hline
\end{tabular}




\section{APPENDIX 1 (Continued)}

Titles of periodicals and publishers by country

$\begin{array}{lccl}\text { Titles of periodicals } & \begin{array}{c}\text { No. of } \\ \text { manuscripts }\end{array} & \text { Country } & \text { Publishing house } \\ \text { Museum Internacional } & 1 & \text { France } & \text { UNESCO } \\ \text { Ceiba } & 1 & \text { Honduras } & \text { Escuela Agrícola Panamericana Zamorano } \\ \text { Herb } & 3 & \text { Unknown } & \text { Unknown } \\ \text { Total } & 181 & & \end{array}$

\section{APPENDIX 2}

Number of authors per article

\begin{tabular}{|c|c|}
\hline $\begin{array}{l}\text { Number } \\
\text { of articles }\end{array}$ & Coauthors to L.D. Gómez \\
\hline 14 & J. Gómez-Laurito \\
\hline 7 & L. Kisimova-Horovitz \\
\hline 6 & R. Singer, E. Wollenweber \\
\hline 5 & F. Oberwinkler \\
\hline 4 & W.H., Jr. Wagner \\
\hline 3 & $\begin{array}{l}\text { C. Chiu-Ming, J. García-Jiménez, C.A. Laurito-Mora,T. Murakami, Y. Saiki, A.L. Valerio-Zamora, F.S. } \\
\text { Wagner, J.W. Wallace }\end{array}$ \\
\hline 2 & S.C. Hsiao, K.E. Malterud, J.D. Mauseth, J.I. Mead, N.Tanaka, C.E Valerio-Gutiérrez \\
\hline 1 & $\begin{array}{l}\text { R.M. Alfaro, G.E. Alvarado-Induni, R.S. Anderson, A. Atmella-Cruz, J. Bergelson, Braker, H.E., J. Bruce, } \\
\text { G. Cooper-Driver, B.I. Crother, R. Cubero-Murillo, C.M. D’Antonio, C.C. Daehler, V.H. Dietz, M. Dörr, } \\
\text { J. Favre-Bonvin, P.H. Gamboa, D.E. Giannasi, J.C. Godoy, D.R. Gordon, D.J. Graham, G.S. Hartshorn, } \\
\text { L.Hartshorn, D.A. Henk, L.R. Hernández-S., O. Herrera-MacBryde, W. Herrera, R.J Hobbs, A. Holt, K.R. } \\
\text { Hopper, C.E. Hughes, S. Imhof, P.H. Jolivet, M. Kappelle, T. Kruckow, M. LaHart, R.R.B Leakey, W.G. Lee, } \\
\text { P.E. León-Azofeifa, R.W. Lichtwardt, L.L.M. Loope, D.H. Lorence, S.M. Louda, S.G Lucas, A.E. Lugo, } \\
\text { K.R. Markham, E. Martínez, A. Mata-Jiménez, L. Mata-Jiménez, P.B. McEvoy, J. Meerman, A. Mendoza, A. } \\
\text { Meyrat, J.T. Mickel, J. Monge-Nájera, J.M. Mora-Benavides, R. Morales, V.V. Méndez-Alvarez, J. Ness, D.J. } \\
\text { O’Dowd, R.A. Ocampo-Sánchez, D.N. Pegler, D.H. Pfister, J.D. Pittillo, D.J. Pool, R.S. Pozner, E.A. Pérez- } \\
\text { Gamboa, B. Pérez-García, L.G. Pérez-Rivera, C.A. Quesada-Mateo, W. Ramírez-Benavides, R. Riba, D.M. } \\
\text { Richardson, C.H.F. Rowell, M. Rowell-Rahier, L. Ryvarden, T. Satake, M. Savage, E. Schmid, A. Sivanesan, } \\
\text { R. Soeder, C. Solera-Mora, A. Solórzano-López, R. Solórzano-Soto, F.G. Stiles, S.L. Swift, J.A. Jr. Tosi-Olin, } \\
\text { A. Ugalde-Víquez, A. Umaña-Quesada, J.L. Villa-Lobos, C. Villalobos, P.M. Vitousek, D. Vreugdenhil, K.S. } \\
\text { Walter, H.C. Weber, R. Weels, D.M. Windsor, D.L. Yopp. }\end{array}$ \\
\hline
\end{tabular}




\section{APPENDIX 3}

Bibliography of Luis Diego Gómez Pignataro, 1968-2010

Alvarado-Induni, G.E., Lucas, S.G. and Gómez Pignataro, L.D. (2008) Evidencias directas e indirectas sobre la probable coexistencia de bisontes y el ser humano en Centroamérica durante el Holoceno. Revista Geológica de América Central. 39, 53-64.

Anderson, R.S. and Gómez Pignataro, L.D. (1997) Systenotelus, a remarkable new genus of weevil (Coleoptera: Curculionidae) associated with Cardulovica (Cyclanthaceae) in Costa Rica and Panamá. Revista de Biología Tropical 45, 887-904.

Bruce, J. and Gómez Pignataro, L.D. (1979) Notes on a survival mechanism for fallen Lycopodium epiphytes. Brenesia 16, 222-223.

Dietz, V.H., Wollenweber, E., Favre-Bonvin, J. and Gómez Pignataro, L.D. (1980) A novel class of complex flavonoids from the frond exudate of Pityrogramma mryolala. Zeitschrift für Naturforschung. Section C, Biosciences 35, 36-40.

Ewel, J.J., O’Dowd, D.J., Bergelson, J., Daehler, C.C., D’Antonio, C.M., Gómez Pignataro, L.D., Gordon, D.R., Hobbs, R.J., Holt, A., Hopper, K.R., Hughes, C.E., LaHart, M., Leakey, R.R.B., Lee, W.G., Loope, L.L., Lorence, D.H., Louda, S.M., Lugo, A.E., McEvoy, P.B., Richardson , D.M. and Vitousek, P.M. (1999) Deliberate introductions of species: research needs: benefits can be reaped, but risks are high. BioScience 49,619-630.

Gómez Pignataro, L.D. (2000) A garden of dreams: a life in Costa Rica. Herb 1, 6-7.

Gómez Laurito, J. and Gómez Pignataro, L.D. (1989) A new hamamelid element from Central America. In: Evolution, Systematics, and Fossil History of the Hamamelidae, vol. 2: 'Higher' Hamamelidae. Crane, P.R.; Blackmore, S. (eds.), pp. 341-342. Oxford: Clarendon Press. GB.

Gómez Laurito, J. and Gómez Pignataro, L.D. (1981) A new species of arborescent Passiflora (Astrophea) from Costa Rica. Phytologia 49, 56-57.

Gómez Laurito, J. and Gómez Pignataro, L.D. (1991) Ticodendraceae: a new family of flowering plants. Annals of the Missouri Botanical Garden 78, 87-88.

Gómez Laurito, J. and Gómez Pignataro, L.D. (1989) Ticodendron: a new tree from Central America . Annals of the Missouri Botanical Garden 76, 1148-1151.
Gómez Pignataro, L.D. (1983) Acrostichum aureum. In: Costa Rican Natural History . D. H. Janzen (ed.), pp. 185-187. Chicago: University of Chicago Press.

Gómez Pignataro, L.D. (1984) Additions to the Costa Rican mycoflora. Plant pathogens. Brenesia 22, 349-352.

Gómez Pignataro, L.D. (1976) Algunos hongos de Costa Rica. Brenesia 8, 104-107.

Gómez Pignataro, L.D. (2000) Animals in folk medicine. Herb 1, 6-7.

Gómez Pignataro, L.D. (1973) Ants and Polypodium polypodioides. American Fern Journal 63, 165.

Gómez Pignataro, L.D. (1997) Areas de conservación en Costa Rica. In: Simposio desarrollo sostenible: la opción para Costa Rica. Memoria. San José. CR. 22-24 Nov., 1997. pp. 73-75. San José: Academia Nacional de Ciencias.

Gómez Pignataro, L.D. (1977) The Azteca ants of Solanopteris brunei. American Fern Journal 67, 31.

Gómez Pignataro, L.D. (1996) Basidiomicetes de Costa Rica: Xerocomus, Chalciporus, Pulveroboletus, Boletellus, Xanthoconium (Agaricales: Boletaceae). Revista de Biología Tropical 44, 59-89.

Gómez Pignataro, L.D. (1983) Beauty and the beast. Brenesia 21,458

Gómez Pignataro, L.D. (1977) The behaviour of an inebriated Opsiphanes cassiae (Brassolidae). Journal of the Lepidopterists' Society 31, 203-204.

Gómez Pignataro, L.D. (1975) Bibliografía geológica y paleontológica de Centroamérica y El Caribe, San José: Museo Nacional de Costa Rica/Departamento de Historia Natural. CR. 125 p.

Gómez Pignataro, L.D. (1994) La biodiversidad de Costa Rica. In: Biodiversidad: políticas y legislación a la luz del desarrollo sostenido. Salazar Cambronero, R.; Cabrera Medaglia, Jorge A.; López Mora, A.(eds.), pp. 27-29. Heredia.: Fundación Ambio. CR.

Gómez Pignataro, L.D. (1974) The biology of the potatofern Solanopteris brunei. Brenesia 4, 37-61. 
Gómez Pignataro, L.D. (1977) Biología de las bromeliaceas. San José: Museo Nacional de Costa Rica. Vol. 1.

Gómez Pignataro, L.D. (1977) La biota bromelícola excepto anfibios y reptiles. Historia Natural de Costa Rica. Biología de las Bromeliáceas 1, 45-62.

Gómez Pignataro, L.D. (1983) Bird's nest fungi. Brenesia $21,464$.

Gómez Pignataro, L.D. (1993) Birds as short-range seed dispersers of Zamia fairchildiana in SW Costa Rica. Revista de Biología Tropical 41, 905-906.

Gómez Pignataro, L.D. (1977) A buck-moth in Costa Rica. Journal of the Lepidopterists' Society 31,75

Gómez Pignataro, L.D. (1994) Checklist of plants of Cerro de la Muerte and other Costa Rican paramos and adjacent forests (Cryptogams excluded). San Vito, Coto Brus: Organization for Tropical Studies. Las Cruces Biological Station. 21 p.

Gómez Pignataro, L.D. (1983) La chicha bruja. Brenesia $19-20,616$.

Gómez Pignataro, L.D. (1996) Conservation in the tropics: the view form within. In: Neotropical biodiversity and conservation. Gibson, A.C. (ed.), pp. 179-184. Los Angeles: Mildred E. Mathias Botanical Garden// Occasional Publication of the Mildred E. Mathias Botanical Garden 1.

Gómez Pignataro, L.D. (1988) The conservation of biological diversity: the case of Costa Rica in the year 2000. In Tropical rainforests: diversity and conservation. Almeda, F.; Pringle. C.M. (eds.), pp. 125-129. San Francisco: Calif. Acad. Sciences and Pac. Div. AAAS. .

Gómez Pignataro, L.D. (1985) Conservation of pteridophytes. Proceedings of the Royal Society of Edinburgh 96B, 431-433.

Gómez Pignataro, L.D. (1978) Contribuciones a la pteridología centroamericana 3. Sertum nicaraguense. Brenesia 14-15, 279-281.

Gómez Pignataro, L.D. (1980) Contribuciones a la pteridología centroamericana 4. Novitates. Brenesia 18 155-170.

Gómez Pignataro, L.D. (1982) Contribuciones a la pteridología centroamericana. 5. Identificación de los géneros de helechos en Centroamérica. Brenesia 19-20, 151-164.

Gómez Pignataro, L.D. (1985) Contribuciones a la pteridología centroamericana. 6. Flora de Nicaragua.I.
Isoetaceae, Equisetaceae, Lycopodiaceae, Selaginellaceae, y los grupos eusporangiados. Brenesia 23, $1-42$.

Gómez Pignataro, L.D. (1976) Contribuciones a la pteridología centroamericana. I. Enumeratio filicum nicaraguensium. Brenesia 8, 41-56.

Gómez Pignataro, L.D. (1977) Contribuciones a la pteridología centroamericana II. Novitates. Brenesia 10-11, 115-119.

Gómez Pignataro, L.D. (1970) Contribuciones a la pteridología costarricense. I. Nuevas especies. Revista de Biología Tropical 17, 105-117.

Gómez Pignataro, L.D. (1972) Contribuciones a la pteridología costarricense. II. Plantae novae vel minus cognitae. Revista de Biología Tropical 20,31-43.

Gómez Pignataro, L.D. (1972) Contribuciones a la pteridología costarricense. III. Dos nuevas especies y una nota sobre Neurocallis Fée . Revista de Biología Tropical 20, 181-187.

Gómez Pignataro, L.D. (1976) Contribuciones a la pteridología costarricense. IX. El género Ophioglossum en Costa Rica. Brenesia 8, 85-95.

Gómez Pignataro, L.D. (1975) Contribuciones a la pteridología costarricense. V. Un caso de apogamia en poblaciones de Trichomanes crinitum Swartz . Brenesia 6, 19-23.

Gómez Pignataro, L.D. (1975) Contribuciones a la pteridología costarricense. VI. El género Peltapteris Link en Costa Rica. Brenesia 6, 25-31.

Gómez Pignataro, L.D. (1975) Contribuciones a la pteridología costarricense. VII. Pteridofitos de la Isla de Cocos Contributions to the Costa Rican pteridology. VII. Pteridophyta of Cocos Island. Brenesia 6, 33-48.

Gómez Pignataro, L.D. (1975) Contribuciones a la pteridología costarricense. VIII. La hibridación en el trópico: Microgramma X Polypodium y P. aspidiolepis Baker. Brenesia 6, 49-57.

Gómez Pignataro, L.D. (1976) Contribuciones a la pteridología costarricense. X. Nuevos pteridófitos de la Isla de Cocos. Brenesia 8, 97-101.

Gómez Pignataro, L.D. (1977) Contribuciones a la pteridología costarricense. XI. Hermann Christ, su vida, obra e influencia en la botánica nacional. Brenesia $12-13,25-79$.

Gómez Pignataro, L.D. (1978) Contribuciones a la pteridología costarricense XII. Carlos Wercklé. Brenesia 14-15, 361-393. 
Gómez Pignataro, L.D. (1979) Contribuciones a la pteridología costarricense. XIII Novitates. Brenesia 16 , 95-100.

Gómez Pignataro, L.D. (1972) Contributions to the Costa Rican pteridology. II. New but little known plants. Revista de Biología Tropical 20,31-43.

Gómez Pignataro, L.D. (1973) Contributions to the Costa Rican pteridology. IV. The genera Cheiloplecton, Schaffneria and Paltonium in Costa Rica. Revista de Biología Tropical 21,91-101.

Gómez Pignataro, L.D. (1973) Costa Rica . Museum Internacional 25, 182-184.

Gómez Pignataro, L.D. (1989) Costa Rica. In: Floristic inventory of tropical countries: the status of plant systematics, collections, and vegetation, plus recommendations for the future. Campbell, D.G.; Hammond, H.D. (eds.), pp. 306-308. New York.: The New York Botanical Garden Press. .

Gómez Pignataro, L.D. (1986) Costa Rica 1:250,000. Tipos de vegetación. San José: Editorial Universidad Estatal a Distancia.

Gómez Pignataro, L.D. (1973) Criptonemiales calcáreas fósiles en las calizas terciarias de Patarrá, Costa Rica. Revista de Biología Tropical 21, 107-110.

Gómez Pignataro, L.D. (1983) Cyatheaceae and Dicksoniaceae. In: Costa Rican Natural History . D. H. Janzen (ed.), pp. 225-228. Chicago: University of Chicago Press.

Gómez Pignataro, L.D. (1983) De fungi. Una selección de Plinio El Viejo. Brenesia 21,437-447.

Gómez Pignataro, L.D. (1977) Dos helechos nuevos para la flora nicaragüense. Brenesia 12-13, 270

Gómez Pignataro, L.D. (1973) Dos helechos pascuences. Revista de Biología Tropical 21,31-32.

Gómez Pignataro, L.D. (1985) Ecology of some neotropical hybrid pteridophytes. Proceedings of the Royal Society of Edinburgh 86B, 347-351.

Gómez Pignataro, L.D. (1994) El desarrollo sostenible visto desde un jardín costarricense. In: Desarrollo Sostenible: la visión desde los países menos industrializados. Documentos Cátedra Franklin Chang. J. Monge N. (ed.), pp. 59-61. San José: EUNED .

Gómez Pignataro, L.D. (1983) Evaluación del Servicio Nacional de Parques Nacionales. Informe presentado al Director del S.P.N. San José: S.P.N.
Gómez Pignataro, L.D. (1999) Exobasidiales and Cryptobasidiales (Basidiomycetes) in the Caribbean Basin. In: International Botanical Congress. XVI. St. Louis, MO. US. 1-7 August, 1999. p. 8.

Gómez Pignataro, L.D. (2005) La exploración científica de los páramos costarricenses. In: Páramos de Costa Rica. Kappelle, M.; Horn, S.P. (eds.), pp. 101-110. Santo Domingo de Heredia: Editorial INBio.

Gómez Pignataro, L.D. (1975) The ferns and fern-allies of Cocos Island, Costa Rica. American Fern Journal 65, 102-104.

Gómez Pignataro, L.D. (1974) Ficus padifolia HBK en la diatomita Pliocena/Pleistocena de la Formación Bagaces, Gte., Costa Rica. Veröffentlichungen aus dem Überseemuseum Bremen 4, 141-148.

Gómez Pignataro, L.D. (1982) A filmy Danaea. American Fern Journal 72, 63-64.

Gómez Pignataro, L.D. (1972) The first Peruvian record of Elaphoglossum cardenasii Wagner. American Fern Journal 62, 95

Gómez Pignataro, L.D. (1968) A first report of fossil fernlike Pteropsida from Costa Rica. Revista de Biología Tropical 16, 255-258.

Gómez Pignataro, L.D. (2000) Flora costaricensis: Family No. 197 Orobanchaceae . Fieldiana. Botany 41, 165-169.

Gómez Pignataro, L.D. (1977) Flora Costaricensis. Family No. 44 Salicaceae. Fieldiana. Botany 40, 14-17.

Gómez Pignataro, L.D. (1983) Flora Costaricensis: Family No 61 Balanophoraceae. Fieldiana. Botany 13, 93-99.

Gómez Pignataro, L.D. (1983) Flora Costaricensis: Hydnoraceae. Fieldiana. Botany 13, 87-89.

Gómez Pignataro, L.D. (1983) Flora Costaricensis: Rafflesiaceae. Fieldiana. Botany 13, 89-93.

Gómez Pignataro, L.D. (1972) Fungi costarricenses nonnulli. I: Clavariaceae novae. Darwiniana 17 , 393-396.

Gómez Pignataro, L.D. (1983) The fungi of Cocos Island, Costa Rica. I. Brenesia 21, 355-364.

Gómez Pignataro, L.D. (1982) Grammitis succinea, the first new world fern found in amber. American Fern Journal 72, 49-52.

Gómez Pignataro, L.D. (1972) Gyromitra chirripoensis nov. sp. Revista de Biología Tropical 20, 131-135. 
Gómez Pignataro, L.D. (1982) Historical and cultural aspects. In: Costa Rica country environmental profile: a field study. , G. S. Hartshorn (ed.,et al), pp. 13-23. San José: Tropical Science Center.

Gómez Pignataro, L.D. (2005) Hongos verdaderos (Eumycota) de los páramos de Costa Rica. In: Páramos de Costa Rica. Kappelle, M.; Horn, S.P. (eds.), pp. 323-341. Santo Domingo de Heredia: Editorial INBio.

Gómez Pignataro, L.D. (1988) Horticulture in Costa Rica. Heliconia Society International Bulletin 3, 8-9.

Gómez Pignataro, L.D. (1973) Hymenophyllopsis hymenophylloides L.D. Gómez, nov.sp., de la Guyana venezolana. Revista de Biología Tropical 21, 103-105.

Gómez Pignataro, L.D. (1976) The identity of Polypodium furfuraceum f. pinnatisectum. American Fern Journal 66, 27

Gómez Pignataro, L.D. (1972) Karatophyllum bromelioides L.D. Gómez (Bromeliaceae), nov. gen. et sp., del Terciario Medio de Costa Rica. Revista de Biología Tropical 20, 221-229.

Gómez Pignataro, L.D. (1970) Las cianoficeas de Costa Rica (I). O’Bios 2, 5-45.

Gómez Pignataro, L.D. (1994) Las ciencias naturales. In: Ideario Nacional de la Ciencia y la Tecnología : "Hacia el nuevo milenio". O. Morales (ed.), pp. 173 182. San José: Ministerio de Ciencia y Tecnología.

Gómez Pignataro, L.D. (1984) Las plantas acuáticas y anfibias de Costa Rica y Centroamérica I. Liliopsida, edn. San José: EUNED. 430 p.

Gómez Pignataro, L.D. (2009) Las plantas y Carlos Darwin. Revista de Biología Tropical 57, 909-913.

Gómez Pignataro, L.D. (1972) Los basidiolíquenes de Costa Rica. Revista de Biología Tropical 20,81-92.

Gómez Pignataro, L.D. (1992) Los Basidiomicetes de Costa Rica. IV. Revisión del género Strobilomyces Berk. (Agaricales, Boletaceae). Brenesia 38, 95-103.

Gómez Pignataro, L.D. (1992) Los Basidiomicetes de Costa Rica: V. Paxillaceae (Agaricales, Boletineae). Brenesia 38, 105-113.

Gómez Pignataro, L.D. (1993) Los Basidiomicetes de Costa Rica: VI. Bondarzewiaceae (Agaricales, Russulineae). Brenesia 39-40, 1-3.
Gómez Pignataro, L.D. (1993) Los Basidiomicetes de Costa Rica: VII. Boletopsidaceae. Brenesia 39-40, 5-6.

Gómez Pignataro, L.D. (1978) Manual de microtécnicas vegetales. Heredia, C.R.: Universidad Nacional. $210 \mathrm{p}$.

Gómez Pignataro, L.D. (1983) Microfibrils in the xylem of Blechnum viviparum. American Fern Journal 73,63

Gómez Pignataro, L.D. (1975) Microgramma piloselloides with furcate fertile fronds. American Fern Journal 65,61

Gómez Pignataro, L.D. (1977) La mosca del cangrejo terrestre Cardisoma crassum Smith (Crustacea: Gecarcinidae) en la Isla del Coco, Costa Rica. Revista de Biología Tropical 25, 59-63.

Gómez Pignataro, L.D. (1980) Moths and ferns. American Fern Journal 70, 111

Gómez Pignataro, L.D. (1972) Neurocallis praestantissi$m a$ in Costa Rica. American Fern Journal 62, 100

Gómez Pignataro, L.D. (1981) A new Mesoamerican quillwort. Phytologia 49, 339-340.

Gómez Pignataro, L.D. (1971) Notas sobre carófitos de Costa Rica. II. Revista de Biología Tropical 19, 105-107.

Gómez Pignataro, L.D. (1976) A note on the young fronds of Ophioglossum palmatum. American Fern Journal 66,27

Gómez Pignataro, L.D. (1980) Notes on the biology of the Central American Orobanchaceae. Brenesia 17, 389-396.

Gómez Pignataro, L.D. (2006) Novedades en la Amazonía Peruana. Lankesteriana 6, 5-7.

Gómez Pignataro, L.D. (1974) Ophiomorpha Lundgren, un fósil-huella en el Plioceno de Costa Rica. Brenesia $4,17-21$.

Gómez Pignataro, L.D. (2000) The Organization for Tropical Studies (O.T.S) ethnobiology course. In: VII International Congress of Ethnobotany: Ethnobiology, benefits sharing and biocultural diversity. Abstracts. University of Georgia, Athens, GA. US. October 23-27, 2000. p. 66-67. Athens, GA University of Georgia. US.

Gómez Pignataro, L.D. (1982) The origin of the pteridophyte flora of Central America. Annals of the Missouri Botanical Garden 69, 548-556. 
Gómez Pignataro, L.D. (2007) Orquídeas centroamericanas en Inglaterra del siglo XIX. Lankesteriana 7, 479-492.

Gómez Pignataro, L.D. (1971) Palmacites berryanum, a new palm fossil from the Costa Rican tertiary. Revista de Biología Tropical 12, 121-132.

Gómez Pignataro, L.D. (1983) Parasitic plants. In: Costa Rican Natural History . D. H. Janzen (ed.), pp. 292298. Chicago: University of Chicago Press.

Gómez Pignataro, L.D. (1982) Plantae mesoamericanae novae. II. Phytologia 50, 401-404.

Gómez Pignataro, L.D. (1982) Plantae mesoamericanae novae. IV. Phytologia 51, 473

Gómez Pignataro, L.D. (1982) Plantae mesoamericanae novae. VI. Phytologia 52, 153-156.

Gómez Pignataro, L.D. (1983) Plantae mesoamericanae novae. VIII. Phytologia 53, 97-100.

Gómez Pignataro, L.D. (1978) Preliminary note on a fossil Equisetum from Costa Rica. Fern Gazette 11, 401-403.

Gómez Pignataro, L.D. (1999) Preserving the fabric of life. Herb 1, 2-3.

Gómez Pignataro, L.D. (1983) Pteridophytes. In: Costa Rican Natural History. D. H. Janzen (ed.), pp. 311318. Chicago: University of Chicago Press.

Gómez Pignataro, L.D. (1974) Revisión de las especies costarricenses del género Helvella Fries. Brenesia $3,31-42$.

Gómez Pignataro, L.D. (1971) Ricerche citologiche sulle Pteridofite della Costa Rica. 1. Atti dell'Istituto Botanico e Laboratorio Crittogamico dell'Universitá di Pavia. Serie 6 7, 29-31.

Gómez Pignataro, L.D. (1983) Searchers on that rich coast: Costa Rican field biology, 1400-1980. In: Costa Rican Natural History . D. H. Janzen (ed.), pp. 1-11. Chicago: University of Chicago Press.

Gómez Pignataro, L.D. (1980) Sobre Blechnum viviparum (Blechnaceae). Brenesia 18, 253-258.

Gómez Pignataro, L.D. (1974) Sobre el género Colonnaria Rafinesque. Revista de Biología Tropical 22, 5-10.

Gómez Pignataro, L.D. (1973) Sobre el género Tonduzia Stevens (Sphaeriales, Ascomycetes). Brenesia 2, 21

Gómez Pignataro, L.D. (1977) Sobre la nomenclatura de Peltapteris. Brenesia 12-13, 269
Gómez Pignataro, L.D. (1975) Sobre Wainiocora Tomase11 (Basidiolichenes). Brenesia 5,73

Gómez Pignataro, L.D. (1978) Some insect interactions with Azolla mexicana. American Fern Journal 68, 60.

Gómez Pignataro, L.D. (1978) Thelypteris oroniensis, a new species from Costa Rica. American Fern Journal $68,9-10$.

Gómez Pignataro, L.D. (1988) Tropical botanic gardens and arboreta in conservation. Botanical Gardens Newsletter 4-5.

Gómez Pignataro, L.D. (1981) Tropisms in Regnellidium diphyllum. Fern Gazette 12, 131-132.

Gómez Pignataro, L.D. (1971) Two new tree ferns from Costa Rica. American Fern Journal 61, 166-170.

Gómez Pignataro, L.D. (1977) Un Melocactus Link \& Otto (Cactaceae) nuevo para Centroamérica. Brenesia $10-11,127-133$.

Gómez Pignataro, L.D. (1971) Un nuevo discomycete operculado de América Central: Morchella herediana, nov. sp. Darwiniana 16,417-426.

Gómez Pignataro, L.D. (1970) Una nota sobre caráceas de Costa Rica. Ceiba 16, 45-49.

Gómez Pignataro, L.D. (1971) Una nueva especie del género Peltapteris Link de los Andes peruanos. Revista de Biología Tropical 18, 217-220.

Gómez Pignataro, L.D. (1994) Una nueva especie neotropical de Termitomyces Helm (Agaricales: Termitomycetaceae). Revista de Biología Tropical 42, 439-441.

Gómez Pignataro, L.D. (1989) Unidades naturales: estado y uso actual de los ecosistemas y recursos naturales, beneficios potenciales y riegos naturales en la región de la Reserva de la Biosfera de Talamanca-Amistad : Consultoría para la OEA. San José: OEA.

Gómez Pignataro, L.D. (1973) An unusual population of Antrophyum lanceolatum. American Fern Journal 63,22

Gómez Pignataro, L.D. (2008) Vanilla planifolia, the first Mesoamericana orchid illustrated, and notes on the la Cruz-Badiano Codex. Lankesteriana 8, 1-88.

Gómez Pignataro, L.D. (1976) Variation in Costa Rican Ophioglossum palmatum and nomenclature of the species. American Fern Journal 66, 89-92.

Gómez Pignataro, L.D. (1983) Variegated squirrels eat fungi, too. Brenesia 21, 458-459. 
Gómez Pignataro, L.D. (1986) Vegetación y clima de Costa Rica: apuntes para una biogeografía costarricense.1. Vegetación.. San José: EUNED. 327 p.

Gómez Pignataro, L.D. (1980) Vegetative reproduction in a Central American Is"etes (Is"etaceae). Its morphological, systematic and taxonomical significance. Brenesia 18, 1-14.

Gómez Pignataro, L.D. (1994) The vernacular names of the birds of Coto Brus. San Vito de Coto Brus: Organization for Tropical Studies, Las Cruces Biological Station. 7 p.

Gómez Pignataro, L.D. (1995) Vernacular names of the commonest timber species of SW Costa Rica. San Vito,Coto Brus: Organization for Tropical Studies. Las Cruces Biological Station. 14 p.

Gómez Pignataro, L.D. (1995) Weinmannia spp. (Cunoniaceae): fitoquímica básica. Revista de Biología Tropical 43, 311-312.

Gómez Pignataro, L.D. and Alfaro, R.M. (1996) Basidiomicetes de Costa Rica. De Russulae novae. Revista de Biología Tropical 44, 25-37.

Gómez Pignataro, L.D. and Gamboa P., H. (1981) Notes on the History of the Museo Nacional de Costa Rica. In: Between continents between seas: precolombian art of Costa Rica. Abel, Suzane (ed.), pp. 11-14. New York: Henry Abrams.

Gómez Pignataro, L.D., Godoy, J.C., Herrera MacBryde, O. and Villa Lobos , J.L. (1995) Central America: regional overview. In: Centres of Plant Diversity: A guide and strategy for their conservation. Vol. 3. The Americas. Davis, S. D., Heywood, V. H., Herrera MacBryde, O., Villa Lobos, J., Hamilton, A. C. (eds.), Washington, DC: WWF for Nature \& I.U.C.N. .

Gómez Pignataro, L.D. and Gómez Laurito, J. (1998) Historia natural y presencia de la "planta insectívora" Drosera capillaris (Droseraceae) en Costa Rica. Revista de Biología Tropical 46, 1033-1037.

Gómez Pignataro, L.D. and Gómez Laurito, J. (1981) A new species of Prosopanche (Hydnoraceae) from Costa Rica. Phytologia 49, 53-55.

Gómez Pignataro, L.D. and Gómez Laurito, J. (1982) Plantae mesoamericanae novae. I. Phytologia 50, 69-70.

Gómez Pignataro, L.D. and Gómez Laurito, J. (1982) Plantae mesoamericanae Novae. III. Phytologia 50, 457-460.
Gómez Pignataro, L.D. and Gómez Laurito, J. (1983) Plantae mesoamericanae novae. IX. Phytologia 53, 447-448.

Gómez Pignataro, L.D. and Gómez Laurito, J. (1982) Plantae mesoamericanae novae. V. Phytologia 51, 474-478.

Gómez Pignataro, L.D. and Gómez Laurito, J. (1982) Plantae mesoamericanae novae. VII. Phytologia 52, 227-229.

Gómez Pignataro, L.D. and Gómez Laurito, J. (1984) Plantae Mesoamericanae Novae. X. Brenesia 22, 352-354.

Gómez Pignataro, L.D. and Gómez Laurito, J. (1986) Plantae mesoamericanae novae. XI. Phytologia 60, 73-76.

Gómez Pignataro, L.D. and Gómez Laurito, J. (1986) Plantae mesoamericanae novae. XIV. Brenesia 25-26, 311-312.

Gómez Pignataro, L.D. and Henk, D.A. (2004) Validation of the species of Septobasidium (Basidiomycetes) described by John N. Couch. Lankesteriana 4, 75-96.

Gómez Pignataro, L.D. and Kisimova Horovitz, L. (1998) Basidiomicetes de Costa Rica. Nuevas especies de Exobasidium (Exobasidiaceae) y registros de Cryptobasidiales. Revista de Biología Tropical 46, 1081-1093.

Gómez Pignataro, L.D. and Kisimova Horovitz, L. (1997) Basidiomicetos de Costa Rica. Exobasidiales, Cryptobasidiales. Notas históricas, taxonómicas y fitogeográficas. Revista de Biología Tropical 45, 1293-1310.

Gómez Pignataro, L.D. and Kisimova Horovitz, L. (2001) A new species of Septobasidium from Costa Rica. Mycotaxon 80, 255-259.

Gómez Pignataro, L.D. and Ryvarden, L. (1985) Inonotus fimbriatus nov. sp. (Hymenochaetaceae, Basidiomycetes). Mycotaxon 23, 291-292.

Gómez Pignataro, L.D. and Savage, M. (1983) The Organization for Tropical Studies (OTS/OET). In: Costa Rican Natural History . D. H. Janzen (ed.), pp. 8-10. Chicago: University of Chicago Press.

Gómez Pignataro, L.D. and Savage, M. (1983) Pteridium aquilinum. In: Costa Rican Natural History . D. H. Janzen (ed.), pp. 308-311. Chicago: University of Chicago Press. 
Gómez Pignataro, L.D. and Singer, R. (1984) Veloporphyrellus, a new genus of Boletaceae from Costa Rica. Brenesia 22, 293-298.

Gómez Pignataro, L.D. and Valerio Gutiérrez, C.E. (1971) Lista preliminar ilustrada de los moluscos fósiles de la Formación Río Banano (Mioceno), Limón, Costa Rica I. In: Instituto Geográfico Nacional. Informe Semestral Enero-Junio, 1971, pp. 43-62. San José: Ministerio de la Presidencia. Instituto Geográfico Nacional. CR. .

Gómez Pignataro, L.D. and Valerio Gutiérrez, C.E. (1973) Lista preliminar ilustrada de los moluscos fósiles de la Formación Río Banano (Mioceno), Limón, Costa Rica, II. In: Instituto Geográfico Nacional. Informe Semestral Enero-Junio, 1973, pp. 11-22. San José: Ministerio de Obras Públicas y Transportes.Instituto Geográfico Nacional. CR. .

Gómez Pignataro, L.D. and Wallace, J.W. (1986) Flavonoids of Phlebodium. Biochemical Systematics and Ecology 14, 407-408.

Gómez Pignataro, L.D. and Walter, K.S. (1980) A double spore wall in Macroglossum. American Fern Journal 70, 45-46.

Gómez Pignataro, L.D. and Wollenweber, E. (1978) Trismeria...trifoliata? American Fern Journal 68, 121-122.

Gómez Pignataro, L.D.(ed.) (1983) Creatividad y enseñanza de las ciencias = Creativity and teaching of Science. San José: CONICIT, 292 p.

Hartshorn, G.S., Hartshorn, L., Atmella Cruz, A. , Gómez Pignataro, L.D., Mata Jiménez, A., Mata Jiménez, L., Morales, R., Ocampo Sánchez, R.A., Pool, D.J., Quesada Mateo, C.A., Solera Mora, C., Solórzano Soto, R., Stiles, F.G., Tosi Olin, J.A.Jr., Umaña Quesada, A., Villalobos, C. and Weels, R. (1982) Costa Rica: perfil ambiental. Estudio de campo. San José. AID. 151 p.

Hernández S., L.R. and Gómez Pignataro, L.D. (1975) Helvella macropus (Fr.) Karst., en Costa Rica. Brenesia 5, 47-49.

Herrera, W. and Gómez Pignataro, L.D. (1993) Mapa de unidades bióticas de Costa Rica. San José: U.S. Fish and Wildlife Service / The Nature Conservancy. CR.

Hsiao, S.C., Mauseth, J.D. and Gómez Pignataro, L.D. (1993) Growth and anatomy of the vegetative body of the parasitic angiosperm Helosis cayennensis (Balanophoraceae). Bulletin of the Torrey Botanical Club 120, 295-309.
Hsiao, S.C., Mauseth, J.D. and Gómez Pignataro, L.D. (1994) Growth and anatomy of the vegetative body of the parasitic angiosperm Langsdorffia hyppogaea (Balanophoraceae). Bulletin of the Torrey Botanical Club 121, 24-39.

Imhof, S., Weber, H.C. and Gómez Pignataro, L.D. (1994) Ein Beitrag zur Biologie von Voyria tenella Hook. und Voyria truncata (Standley) Standley \& Steyermark (Gentianaceae). Beiträge zur Biologie der Pflanzen 68, 113-123.

Jirón, L.F, Sancho de Barquero, M.E. and Gómez Pignataro, L.D.(ed.). (1983) Indice de publicaciones entomológicas de Costa Rica, San José: CONICITOTS.303 p.

Kappelle, M. and Gómez Pignataro, L.D. (1992) Distribution and diversity of montane pteridophytes of the Chirripó National Park, Costa Rica. Brenesia 37, 67-77.

Kisimova Horovitz, L., Oberwinkler, F. and Gómez Pignataro, L.D. (2000) Basidiomicetos resupinados de Costa Rica. Especies nuevas o raras de Atractiellales (Auriculariales s.1.), Exidiaceae, Sirobasidiaceae y Tremellaceae. Revista de Biología Tropical 48, 539-554.

Kisimova Horovitz, L., Oberwinkler, F. and Gómez Pignataro, L.D. (1997) Basidiomicetos resupinados de Costa Rica. Exidiaceae (Tremellales). Revista de Biología Tropical 45, 1325-1347.

Kisimova Horovitz, L., Oberwinkler, F. and Gómez Pignataro, L.D. (1997) Basidiomicetos resupinados de Costa Rica. Litschauerella, Subulicystidium y Tubulicium (Corticiaceae s.1.). Revista de Biología Tropical $45,1311-1325$.

Kisimova Horovitz, L., Oberwinkler, F. and Gómez Pignataro, L.D. (2000) Basidiomicetos resupinados de Costa Rica. Myxariaceae s. Jülich, Sebacinaceae Wells \& Oberw., y Tremellodendropsidaceae Jülich. Revista de Biología Tropical 48, 519-538.

Kruckow, T. and Gómez Pignataro, L.D. (1974) Notes on the palaeoecology of the fossil algae of Costa Rica. I. Brenesia 4, 23-29.

Laurito Mora, C.A., Valerio Zamora, A.L., Gómez Pignataro, L.D., Mead, J.I., Pérez Gamboa, E.A. and Pérez Rivera, L.G. (2005) A Trionychidae (Reptilia: Testudines, Cryptodira) from the Pliocene of Costa Rica, Southern Central America. Revista Geológica de América Central 32 , 7-11.

León Azofeifa, P.E., Ugalde Víquez, A. and Gómez Pignataro, L.D. (1985) Hacia un manifiesto conservacionista. Biocenosis 2, 25-27. 
Lichtwardt, R.W. and Gómez Pignataro, L.D. (1993) A new Coelomomyces pathogenic to mosquitoes in Costa Rica. Revista de Biología Tropical 41, 407410 .

Malterud, K.E., Wollenweber, E. and Gómez Pignataro, L.D. (1979) The wax of Calathea lutea (Marantaceae). Zeitschrift für Naturforschung. Section C, Biosciences 34, 157-158.

Martínez, E. and Gómez Pignataro, L.D. (1994) Triuridaceae. In: Flora Mesoamericana. Vol 6. Alistamataceae a Cyperaceae. G. Davidse, M. Sousa, and A. O. Chater (eds.), pp. 18-19. México: UNAM, Missouri Bot. Garden, Natural History Museum London.

Mead, J.I., Cubero Murillo, R., Valerio Zamora, A.L., Swift, S.L., Laurito Mora, C.A. and Gómez Pignataro, L.D. (2006) Plio-pleistocene Crocodylus (Crocodylia) from southwestern Costa Rica. Studies on Neotropical Fauna and Environment 41, 1-7.

Mora Benavides, J.M., Méndez Alvarez, V.V. and Gómez Pignataro, L.D. (1999) White-nosed coati Nasua narica (Carnivora: Procyonidae) as a potential pollinator of Ochroma pyramidale (Bombacaceae). Revista de Biología Tropical 47, 719-721.

Pegler, D.N. and Gómez Pignataro, L.D. (1994) An unusual member of the cage fungus family. The Mycologist 8, 54-59.

Pfister, D.H. and Gómez Pignataro, L.D. (1978) On a collection of Wynnea americana from Costa Rica with some comments on the distribution and delimitation of Wynnea species in the neotropics. Brenesia 14-15, 395-400.

Pérez García, B., Mendoza, A., Riba, R. and Gómez Pignataro, L.D. (2001) Development of the sexual phase of Pseudocolysis bradeorum (Polypodiaceae). American Fern Journal 91, 214-226.

Ramírez Benavides, W. and Gómez Pignataro, L.D. (1978) Production of nectar and gums by flowers of Monstera deliciosa (Araceae) and of some species of Clusia (Guttiferae) collected by New World Trigona bees. Brenesia 14-15, 407-412.

Rowell, C.H.F., Rowell Rahier, M., Braker, H.E., Cooper Driver, G. and Gómez Pignataro, L.D. (1983) The palatability of ferns and the ecology of two tropical forest grasshoppers. Biotropica 15, 207-216.

Satake, T., Murakami, T., Saiki, Y., Chiu Ming, C. and Gómez Pignataro, L.D. (1984) Chemical and chemotaxonomical studies on Filices. LI. Chemical studies on the constituents of Costa Rican ferns. Chemical \& Pharmaceutical Bulletin 32, 4620-4624.
Schmid, E., Oberwinkler, F. and Gómez Pignataro, L.D. (1995) Light and electron microscopy of a hostfungus interaction in the roots of some epiphytic ferns from Costa Rica. Canadian Journal of Botany 73, 991-996.

Singer, R., García Jiménez, J. and Gómez Pignataro, L.D. (1990) The Boletineae of Mexico and Central America I \& II. Nova Hedwigia 98, 1-70.

Singer, R., García Jiménez, J. and Gómez Pignataro, L.D. (1991) The Boletineae of Mexico and Central America III. Nova Hedwigia 102, 1-97.

Singer, R., García Jiménez, J. and Gómez Pignataro, L.D. (1992) The Boletineae of Mexico and Central America IV. Nova Hedwigia 105, 1-62.

Singer, R. and Gómez Pignataro, L.D. (1982) Basidiomycetes of Costa Rica. I. Brenesia 19-20, 31-47.

Singer, R. and Gómez Pignataro, L.D. (1984) The basidiomycetes of Costa Rica. III. The genus Phylloporus (Boletaceae). Brenesia 22, 163-181.

Sivanesan, A. and Gómez Pignataro, L.D. (1985) The teleomorph of Sphaceloma erythrinae. Transactions of the British Mycological Society 85, 370-374.

Solórzano López, A., Monge Nájera, J., Gómez Pignataro, L.D. and Crother, B.I. (1998) Redescription and validation of Bothriechis supraciliaris (Serpentes: Viperidae). Revista de Biología Tropical 46, 453-462.

Tanaka, N., Murakami, T., Saiki, Y., Chiu Ming, C. and Gómez Pignataro, L.D. (1981) Chemical and chemotaxonomical studies of ferns. XXXVII. Chemical studies on the constituents of Costa Rican ferns. Chemical \& Pharmaceutical Bulletin 29,3455-3463.

Tanaka, N., Murakami, T., Saiki, Y., Chiu Ming, C. and Gómez Pignataro, L.D. (1978) Chemische untersuchungen von Pteris grandifolia L. Chemical \& Pharmaceutical Bulletin 26, 3580-3582.

Valerio Zamora, A.L., Laurito Mora, C.A. and Gómez Pignataro, L.D. (2005) Un Gliptodonte (Xenarthra, Cingulata) de la localidad de Chachagua, provincia de Alajuela, Costa Rica. Revista Geológica de América Central 32, 61-63.

Vreugdenhil, D., Meerman, J., Meyrat, A., Gómez Pignataro, L.D. and Graham, D.J. (2002) Map of the ecosystems of Central America: Final report. Washington, D.C. World Bank. US. 56 p.

Wagner, W.H.Jr. and Gómez Pignataro, L.D. (1971) Field research of ferns in Costa Rica: Ophioglossum, Dictyoxiphium, Pleuroderris. Ann Arbor: The Matthaei Botanical Gardens of the University of Michigan, $4 \mathrm{p}$. 
Wagner, W.H.J., Wagner, F.S. and Gómez Pignataro, L.D. (1972) The Central American fern genus Pleuroderris: its origin and significance. American Journal of Botany 59, 677

Wagner, W.H.J., Wagner, F.S. and Gómez Pignataro, L.D. (1977) An enigmatic polypody fern from Cartago, Costa Rica. Brenesia 12-13, 81-103.

Wagner, W.H.J., Wagner, F.S. and Gómez Pignataro, L.D. (1978) The singular origin of a Central American fern, Pleuroderris michleriana. Biotropica 10 , 254-264.

Wallace, J.W., Markham, K.R., Giannasi, D.E., Mickel, J.T., Yopp, D.L., Gómez Pignataro, L.D., Pittillo, J.D. and Soeder, R. (1982) A survey for 1,3,6,7-tetrahydroxyC-glycosylxanthones emphasizing the "primitive" leptosporangiate ferns and their allies. American Journal of Botany 69, 360-362.

Wallace, J.W., Pozner, R.S. and Gómez Pignataro, L.D. (1983) A phytochemical approach to the
Gleicheniaceae. American Journal of Botany 70, 207-211.

Windsor, D.M., Ness, J., Gómez Pignataro, L.D. and Jolivet, P.H. (1999) Species of Aulacoscelis Duponchel and Chevrolat (Chrysomelidae) and Nomotus Gorham (Languriidae) feed on fronds of Central American cycads. The Coleopterists Bulletin 53, 217-231.

Wollenweber, E., Dörr, M. and Gómez Pignataro, L.D. (1996) Exudate flavonoids in Godmania aesculifolia (Bignoniaceae). Biochemical Systematics and Ecology 24, 481-482.

Wollenweber, E. and Gómez Pignataro, L.D. (1979) Flavonoid patterns in the farina of Notholaena affinis, a gymnogrammoid fern. Brenesia 16, 123-129.

Wollenweber, E., Malterud, K.E. and Gómez Pignataro, L.D. (1981) 9(11)-Fernene and its 21-epimer as an epicuticular layer on ferns. Zeitschrift für Naturforschung. Section C, Biosciences 34, 896-899.

Edited by Daisy Arroyo 